\title{
Democrats consider playing trump card in effort to pass Obama's health reforms
}

Published at www.cmaj.ca on Mar. 1

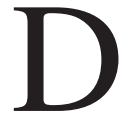
emocrats pushing for an overhaul of health care in the United States came out of an intense Feb. 25 White House conference with their Republican opponents voicing a renewed determination to move forward with President Barack Obama's plan. Not because they reached agreement across party lines, but because they did not.

The session, first of its kind in the memory of most legislators, underscored the great divide between the two parties. For leaders of Congress, and apparently for Obama himself, that proved clarifying, if not liberating.

Rather than negotiate watered-down reforms in hopes of bringing a few key Republicans on side, Democrats now are favouring a more daring path that would preserve most of what Obama set out to do: extend health coverage to more than 30 million uninsured people, control costs and protect people from arbitrary insurance terminations.

It's risky because this is a congressional election year, with the Democrats' control of the House of Representatives and Senate at stake in November and therefore Obama's overall agenda in the balance. Americans are deeply split over his plan, at once suspicious about federal intervention in their health care and unhappy with the status quo.

Obama ended more than six hours of nationally televised talks with lawmakers on Feb. 25 with a parting plea for Republicans to work with him. He also gave a clear signal he's prepared to take the political risks of proceeding without them.

In a system of government without any counterpart to a Canadian-style question period, it was a rare chance to witness the leader and legislators going head to head on the issue of health care at the highest level.

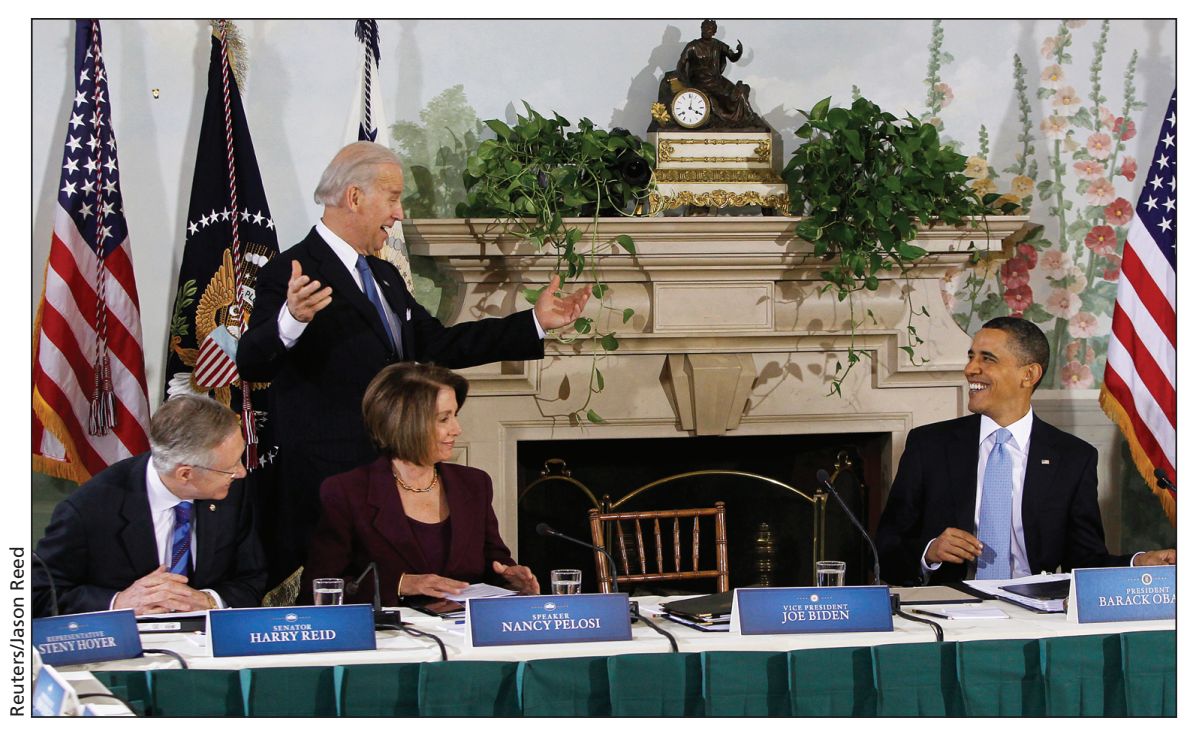

United States President Barack Obama (right) watches as Vice-President Joe Biden (standing) reacts to being asked by Obama to sit down, at the start of a bipartisan meeting with lawmakers to discuss health reform legislation at Blair House in Washington, DC, on Feb. 25. Watching is Senate Majority Leader Harry Reid (Democrat-Nevada) and House Speaker Nancy Pelosi (Democrat-California).

"We cannot have another year-long debate about this," Obama said impatiently in closing a forum that featured frayed tempers, flashes of humour and acres of substantive policy talk that seemed to change no minds at the table.

Unless Republicans come on board, he said, "we've got to go ahead and make some decisions, and then that's what elections are for. We have honest disagreements about the vision for the country and we'll go ahead and test those out over the next several months 'til November. All right?"

Republicans were unyielding. They argued that Obama's plan is a federal power grab that can't be redeemed in negotiation.

Republican Representive Peter Roskam of Illinois told Obama to shake it like an Etch A Sketch until it's blank and begin anew with incremental steps. "Put that on the shelf," added Senator Mitch McConnell of Kentucky, leader of Senate Republicans. "Start over with a blank piece of paper."
Until recently, shelving the plan was a distinct possibility, for Obama's fortunes on this issue have swung like temperatures on a fever chart.

His fellow Democrats were on the verge of passing comprehensive health legislation earlier this year, needing only to settle sticky differences between their own ranks in the House and Senate, when a Republican upset in a special Senate election in Massachusetts left them flailing (CMAJ 2010. DOI: $10.1503 / \mathrm{cmaj} .109-3175)$. It deprived them of the 60-vote threshold needed to overcome endless Republican delaying tactics in the Senate.

It also tested their will to move on health care as they interpreted the Massachusetts result and an array of opinion polls as a commandment from voters to make jobs the top priority.

But the bipartisan summit marked another shift, back to the side of action.

"Whenever Obama inserts himself into the process, things move," says Kathryn Bakich, senior vice-president 
and national health care compliance leader at the Segal Company, which provides benefits consulting for US and Canadian employers.

After months of letting congressional Democrats shape the package, Obama released his own in late February. It was patterned after a bill already passed by the Senate, with some concessions to legislation adopted by the House (CMAJ 2010.DOI: 10.1503/cmaj.1093148).

In essence, the initiative would obligate Americans to have health coverage, provide subsidies to those who can't afford it and establish a new marketplace where people who are not covered under employer plans could buy affordable policies.

The package, stripped of the option of a government-run health plan to compete in the marketplace, remains a far cry from Canada's single-payer system. Yet it is historic change for an American system that has proved resistant to reform for a century.

So what now?

Democrats are considering a parliamentary manoeuvre called reconciliation that would allow final Senate passage with a simple majority of 51 votes. An end-run around the opposition, reconciliation is uncommon and controversial. But it gained favour after Republicans shunned Obama's outreach.

"That's probably the best bet they have," Bakich says.

But the Democrats must first resolve differences among themselves in another messy round of horsetrading.

The task was cast in Biblical terms by the longest-serving House member. Democratic Representative John Dingell of Michigan, age 83, has introduced a universal health care bill in every term since 1957 . In the summit's closing moments, he remarked that he's known other lawmakers in the room since "before they were virgins."

"We have before us a hideous challenge," he said. "The last perfect legislation that was presented to mankind was delivered to the Israelis at the base of Mount Sinai. It was on stone tablets written in the fingers of God."

He went on: "What we're going to do is not perfect. But it sure will make it better and it's going to ease a huge amount of pain." - Cal Woodward, Washington, DC

DOI:10.1503/cmaj.109-3198 